\title{
Respiratory acidosis in hypothermic myxoedema coma
}

\author{
K. D. Buchanan \\ M.B.(Glas.), M.R.C.P., M.R.C.P.E., M.R.C.P.G. \\ Senior Registrar in Medicine \\ J. M. REID \\ M.B.(Glas.), F.F.A.R.C.S.(Eng.) \\ Consultant in Anaesthetics \\ M. T. MCKIDDIE \\ M.B.(St.And.), M.R.C.P., M.R.C.P.G. \\ Registrar in Medicine
}

The Royal Infirmary, Glasgow

Hymans (1963) has recently reviewed sixty-eight cases of hypothermic myxoedema coma and added one further case. Of these sixty-nine cases only twenty have recovered. The mortality appears to be related to the severity of the hypothermia, only three cases having recovered whose rectal temperature was less than $90^{\circ} \mathrm{F}\left(32^{\circ} \mathrm{C}\right)$.

Nordqvist et al. (1960) described respiratory acidosis associated with myxoedema coma but this has received scant mention elsewhere. We consider, as does Nordqvist, that awareness of the possible presence of respiratory acidosis in myxoedema coma may be life-saving. It is for this reason that we report a case of hypothermic myxoedema coma associated with severe respiratory acidosis.

\section{Case report}

The patient, a 66-year-old housewife, was admitted to a surgical unit on 9 February 1964 because of a fractured neck of left femur. She had been on 'thyroid pills for about 5 years', although a definitive diagnosis of hypothyroidism had never been made. ECG: evidence of postero-lateral myocardial ischaemia. Serum cholesterol 210 $\mathrm{mg} / 100 \mathrm{ml}$. Radio-iodine studies (19 March 1964): 24-hr uptake $5 \%$; total plasma iodine of $0.63 \%$ dose $/ 1$, protein-bound iodine $0.04 \%$ dose $/ 1$ both at $48 \mathrm{hr}$ (thyroid therapy was omitted on admission).

As the clinical diagnosis was in doubt and as the possibility of recent iodide ingestion was raised further treatment was postponed. After delayed union of the fracture she was discharged home on 19 June 1964 still without thyroid therapy. She did not attend for follow up. On 11 October 1964 her general practitioner diagnosed bronchopneumonia. She became increasingly drowsy over the next 2 days and was re-admitted in coma on 14 October 1964. The illness coincided with the first cold weather of the winter.
On admission she was deeply unconscious and corpse-like. Her skin was deathly cold and her face oedematous. Her eyebrows were sparse and her hair dry. She was generally flaccid and no tendon reflexes could be elicited. The pulse and blood pressure were unrecordable and the heart sounds were faint with a regular rhythm and a rate of $50 / \mathrm{min}$. Her respirations were exceedingly shallow and she was grossly cyanosed. Rectal temperature $78^{\circ} \mathrm{F}\left(25 \cdot 5^{\circ} \mathrm{C}\right)$.

Investigations (Micro-Astrup, capillary blood) $\mathrm{pH} 6.9, \mathrm{PCO}_{2}>150 \mathrm{mmHg}$. Base excess -8.5 $\mathrm{mEq} / 1$ standard bicarbonate $18.5 \mathrm{mEq} / 1$ and buffer base $44.5 \mathrm{mEq} / 1$, measured at $38^{\circ} \mathrm{C}$ (Astrup, 1959 ; Andersen et al., 1960). Blood electrolytes: $\mathrm{Cl} 99 \mathrm{Na} 129$ and $\mathrm{K} 4 \cdot 1 \mathrm{mEq} / 1$. Blood urea $55 \mathrm{mg} / 100 \mathrm{ml}$, cholesterol $280 \mathrm{mg} / 100 \mathrm{ml}$, glucose $144 \mathrm{mg} / 100 \mathrm{ml}$, calcium $4.7 \mathrm{mEq} / 1$. Liver function tests: no abnormality apart from an albumin of $2.9 \mathrm{~g} / 100 \mathrm{ml}$. ECG: sinus rhythm, rate $55 / \mathrm{min}$, with a coarse somatic tremor; LAD, left ventricular 'strain' with inverted $\mathrm{T}$ waves. $\mathrm{Hb} 10.9$ $\mathrm{g} / 100 \mathrm{ml}$, PCV 33\%, MCHC $33 \%$, WBC $3850 / \mathrm{mm}^{3}$, normochromic, normocytic red cells, ESR $22 \mathrm{~mm} / \mathrm{hr}$ (Westergren).

There was no protein-bound iodine detectable in her blood on two estimations. An EEG revealed continuous, moderate voltage, slow activity from all parts of the brain, and the findings were symmetrical. A chest $X$-ray showed complete opacification of the left hemithorax which was consistent with absorption atelectasis with some effusion.

Because excessive bleeding was noted from capillary puncture, investigations of her haemostatic mechanism were undertaken during her severely hypothermic period and gave the following results: clotting time $10 \mathrm{~min}$, platelet count $96,000 / \mathrm{mm}^{3}$ within $3 \mathrm{hr}$ of admission and $103,000 / \mathrm{mm}^{3}$ the following morning, prothrombin time and thromboplastin generation test both within normal limits. 
TABLE 1

\begin{tabular}{|c|c|c|c|c|c|}
\hline $\begin{array}{c}\text { Time from } \\
\text { admission } \\
\text { (hr) }\end{array}$ & $\begin{array}{c}\text { Rectal } \\
\text { temperature } \\
\left({ }^{\circ} \mathrm{C}\right)\end{array}$ & pH & $\underset{(\mathrm{mmHg})}{\mathrm{PcO}_{2}}$ & $\begin{array}{l}\text { Base excess } \\
(\mathrm{mEq} / \mathrm{l})\end{array}$ & $\begin{array}{c}\text { Relevant features of } \\
\text { treatment }\end{array}$ \\
\hline 0 & $25 \cdot 5$ & 6.9 & 150 & $-8 \cdot 5$ & $\begin{array}{l}10 \mu \mathrm{g} \text { tri-iodothyronine } \\
\text { orally, } \\
100 \mathrm{mg} \text { hydrocortisone i.v. } \\
\text { IPPV, oxygen and } \\
100 \mathrm{mEq} \mathrm{NaHCO} \\
\end{array}$ \\
\hline$+2 \cdot 75$ & 28 & $7 \cdot 38$ & 34 & -4 & $20 \mu \mathrm{g}$ tri-iodothyronine i.v. \\
\hline+5 & $28 \cdot 5$ & $7 \cdot 52$ & 19 & -5 & $\begin{array}{l}\text { IPPV adjusted, } \\
100 \mathrm{mg} \text { hydrocortisone }\end{array}$ \\
\hline$+16 \cdot 5$ & 33 & $7 \cdot 52$ & 26 & +1 & $\begin{array}{l}20 \mu \mathrm{g} \text { tri-iodothyronine, } \\
100 \mathrm{mg} \text { hydrocortisone }\end{array}$ \\
\hline+24 & 33 & $7 \cdot 49$ & 27 & 0 & $100 \mathrm{mg}$ hydrocortisone \\
\hline
\end{tabular}

NoTEs: 1. Rewarming without recourse to electric blankets, etc.

2. Soluble penicillin was given in a dose of 500,000 units b.d. Metaraminol was constantly infused.

Initially continuous oxygen at a flow-rate of 4-6 $1 / \mathrm{min}$ was given by nasal catheter, $10 \mu \mathrm{g}$ of tri-iodothyronine were given by stomach tube, and $100 \mathrm{mg}$ hydrocortisone intravenously. There was no apparent response to this and the bloodpressure and pulse remained unrecordable.

When the Micro-Astrup revealed a severe respiratory acidosis the patient was intubated with an 8 cuffed endotracheal tube and intermittent positive pressure ventilation (IPPV) commenced using $100 \%$ oxygen (Barnet Ventilator). Metaraminol was given intravenously, and to correct the metabolic acidosis, $100 \mathrm{mEq}$ of an $8.4 \%$ solution of sodium bicarbonate was infused.

There was an almost immediate response in that the systolic blood-pressure rose to $180 \mathrm{mmHg}$, the cyanosis became less and she became aware of her surroundings although the rectal temperature was only $78^{\circ} \mathrm{F}\left(26^{\circ} \mathrm{C}\right)$.

Treatment was continued as follows: triiodothyronine intravenously $20 \mu \mathrm{g}$ every $12 \mathrm{hr}$, $100 \mathrm{mg}$ hydrocortisone intravenously 8 hourly, $\frac{1}{2}$ million units of soluble penicillin i.m. twice daily, intravenous fluids limited to 1.5 litres in the day and, as the patient was unable to maintain a blood pressure, this included a continuous infusion of metaraminol. No active rewarming was attempted.

IPPV was continued using the Micro-Astrup technique at frequent intervals to monitor the changes in acid-base state (Table 1). Two and three-quarter hours later the rectal temperature was $82^{\circ} \mathrm{F}\left(28^{\circ} \mathrm{C}\right), \mathrm{pH} 7 \cdot 38, \mathrm{Pco}_{2} 34 \mathrm{mmHg}$, standard bicarbonate $21 \mathrm{mEq} / 1$, Base excess$4 \mathrm{mEq} / 1$, and buffer base $4 \mathrm{mEq} / 1$. There were twitching movements of the right arm and leg, the limbs were generally spastic, and tendon reflexes could now be elicited.

On 15 October 1964 she had several right-sided focal seizures but these were controlled by intramuscular sodium phenobarbitone. She remained spastic. The temperature had now risen to $92^{\circ} \mathrm{F}$ $\left(33^{\circ} \mathrm{C}\right)$.

By 16 October 1964 the temperature had risen to $94^{\circ} \mathrm{F}\left(34.5^{\circ} \mathrm{C}\right)$ and the tri-iodiothyronine was now given by gastric tube. The blood pressure could be maintained without metaraminol and the hydrocortisone was withdrawn. IPPV was still required and therefore a tracheostomy was performed.

On the following day her condition was less satisfactory. The temperature fell to $91^{\circ} \mathrm{F}\left(32.5^{\circ} \mathrm{C}\right)$ and it was again necessary to maintain the bloodpressure with metaraminol. Oliguria had developed and the blood urea rose to $113 \mathrm{mg} / 100 \mathrm{ml}$. Cardiac arrest developed, thoracotomy was performed and ventricular asystole diagnosed. Normal rhythm was restored with difficulty. $200 \mathrm{ml}$ of $8.4 \%$ sodium bicarbonate were required to correct metabolic acidosis. The patient's pupils were then slightly dilated. She died the following day.

\section{Necropsy}

Fibrous, smooth, thyroid weighing $23 \mathrm{~g}$; mostly replaced with fibrous and lymphoid tissue. Small areas with acini were present but these showed no colloid. The pituitary showed no abnormality. The heart $(510 \mathrm{~g})$ was greatly enlarged, hypertrophy mainly involving the left side. There was a diffuse patchy myocardial fibrosis and gross atheromatous changes of the coronary, aorta and cerebral vessels. The right coronary and anterior 
descending branch of the left coronary were severely stenosed. A bronchopneumonia was present. No obvious abnormality was detected in the brain.

\section{Discussion \\ The respiratory acidosis}

Nordqvist et al. (1960) have rightly stressed that $\mathrm{CO}_{2}$ retention can occur in myxoedema coma. It is likely that the progressive depression of the respiratory and cardiovascular systems which are seen in induced hypothermia (Brooks, 1962) will occur in the hypothermia of myxoedema coma, and it is probable that these factors are the basis of the severe respiratory and moderate metabolic acidosis, seen in this patient.

Owing to the poor peripheral circulation, sampling of the acid-base state on capillary blood is questionable, but repeated arterial punctures did not seem justified at the time, owing to the bleeding tendency and the presence of widespread atherosclerosis. Comparison of themacid-base state at intervals was considered to be more important than the values obtained at any one time.

Some improvement in the level of unconsciousness occurred after administering the bicarbonate and commencing IPPV, although only a very slight rise in temperature was noted. As it is now recognized (Brooks, 1962) that consciousness can be present below a body temperature of $28^{\circ} \mathrm{C}$, our clinical impression that this improvement was related to the correction of acidosis appears to be justifiable.

\section{Tri-iodothyronine}

Rapidly acting tri-iodothyronine is the logical treatment for myxoedema coma, but a dose regime has never been scientifically established. Neilson \& Ranlov (1964) remark that, in successfully treated patients, the dose of tri-iodothyronine is usually greater than the dose in cases with a fatal outcome. However, because of the high incidence of coronary artery disease in elderly myxoedematous patients (Means, de Groot \& Stanbury, 1963) caution must be exercised in the administration of the drug. The mean dose of the successful and temporarily successful cases in the literature has been calculated by Neilson \& Ranlov to be $153 \mu \mathrm{g} /$ day. We gave much less, $20 \mu \mathrm{g}$ b.d., but despite this there was obvious improvement. It would also seem logical to give the drug by continuous intravenous infusion. After the temperature had risen from critically low levels there may have been some justification in reducing the dose for we knew that the patient had myocardial disease.

\section{Bleeding tendency}

Orr (1962) reported three patients with myxoedema coma who exhibited a bleeding tendency. One of his patients had a low platelet count but, although platelet counts were not performed in the other two patients, no cause for the haemostatic defect was elicited. The abnormalities demonstrated in the present patient were the prolonged bleeding time and platelet counts which are at a rather low level. Thrombocytopenia is reported in hypothermia in dogs (Villalobos et al., 1958) and capillary fragility is increased in hypothyroidism (Blackburn, 1959). A combination of these two factors may have some part to play in the haemostatic defect. It is interesting to note that the bleeding tendency improved rapidly as the temperature rose.

\section{Summary}

A patient with hypothermic myxoedema coma with severe respiratory acidosis is described. It is suggested that the initial assessment of myxoedema coma should include that of the acid-base state.

\section{References}

ANDERSON, O.S., ENGel, K., Jogensen, K. \& Astrup, P. (1960) A micro method for determination of $\mathrm{pH}$, carbon dioxide tension, base excess and standard bicarbonate in capillary blood. Scand. J. clin. Invest. 12, 172.

ASTRUP, P. (1959) Symposium on $\mathrm{pH}$ and Blood Gas Measurement (Ed. by R. F. Woolmer). Churchill, London.

Blackburn, E.K. (1959) Haemorrhagic states. Postgrad. med. J. 35, 519.

BROOKS, D.K. (1962) Modern Trends in Anaesthesia. Butterworth, London.

HyaMS, D.E. (1963) Hypothermic myxoedema coma. Brit. J. clin. Pract. 17, 1.

Means, J.H., DE GroOt, L.J. \& StanbuRY, J.B. (1963) The Thyroid and its Diseases, 3rd edn, p. 303. McGraw-Hill, New York.

NeILSON, P.E. \& RANLOV, P. (1964) Myxoedema coma. Acta endocr. 45, 353.

NordQVist, P., DHUNER, K.G., STEnberG, K. \& ORNDAHL, G. (1960) Myxoedema coma and $\mathrm{CO}_{2}$ retention. Acta med. scand. 166, 189.

ORR, F.R. (1962) Haemorrhage in myxoedema coma. Lancet, ii, 1012.

Villalobos, T.J., Adelson, E., Riley, P.A. \& CrosBY, W.H. (1958) A cause of thrombocytopenia and leukopenia that occur in dogs during deep hypothermia. J. clin. Invest. 37, 1. 